FOLIA POMERANAE UNIVERSITATIS TECHNOLOGIAE STETINENSIS

Folia Pomer. Univ. Technol. Stetin., Oeconomica 2019, 353(95)2, 41-52

Katarzyna WAWRZYNIAK, Iwona BĄK*

\title{
THE PROFILE OF CANDIDATES FOR STUDIES AND THEIR LEARNING OUTCOMES
}

Department of Mathematical Economics, West Pomeranian University of Technology in Szczecin, Klemensa Janickiego 31, 71-270 Szczecin, Poland, ORCID: 0000-0003-4161-3877, e-mail: katarzyna.wawrzyniak@zut.edu.pl

* Department of Mathematical Economics, West Pomeranian University of Technology in Szczecin, Klemensa Janickiego 31, 71-270 Szczecin, Poland, ORCID: 0000-0001-8959-7269,

Iwona.bak@zut.edu.pl

Summary. The aim of the research presented in the article is to answer the question about how the applicants' skills - measured according to, for instance, their matriculation examination results (for full-time 1st cycle program students) or their average grade awarded in the 1st cycle program (for full-time 2nd cycle program students) - may affect their achievement of learning outcomes. In order find the answer, the dependence between the students' skills and their learning outcomes was analyzed using measures of the strength and direction of the relationship, as well as logistic regression. The database of candidates applying for enrollment with the Faculty of Economics of the West Pomeranian University of Technology in Szczecin, Poland, registered in the Online Recruitment System for the academic year 2015/2016, was used as the information basis.

Key words: applicants to the Faculty, learning outcomes, measures of the strength and direction of the relationship, logistic regression, bootstrap method.

\section{INTRODUCTION}

Over the last twenty-seven years significant changes to the numbers of higher education institutions (HEls) and their students have been observed in Poland. In the academic year 1990/1991 the country had 112 HEls, which hosted 404 thous. students. Fifteen years later (2005/2006) the number of such schools grew to 445, with 1,953.8 thous. students. After 2006, a slight increase in the number HEls could be seen as accompanied by a drop in the number of students. For instance, there were $460 \mathrm{HEls}$ in the academic year 2010/2011 that provided education to $1,841.3$ thous. Starting from the following academic year, both the number of HEls and their students kept falling systematically, with $453 \mathrm{HEls}$ and 1,677 thous. students in the academic year 2012/2013, $434 \mathrm{HEls}$ and 1,469.4 thous. students two years later (2014/2015) and $397 \mathrm{HEls}$ and 1,291.1 thous. students in the academic year 2017/2018 (Rocznik Statystyczny Rzeczypospolitej Polskiej 2004, 2013, 2015, 2018; Mikuła-Bączek 2016). This shows that over the last eight years (between 2010/2011 and 2017/2018) the number of HEls dropped by 63 (or 14\%), and that of their students fell by 500 thous. (or 30\%). The decreasing number of students compels the institutions to adopt modern teaching methods in order to attract applicants. Therefore, rivalry between the HEls has centered around the quality of instruction, with an ever more modern teaching offer improving their attractiveness. 
Nevertheless, very often it is not the attractive courses of study or state-of-the-art teaching methods that are critical in choosing where to apply, but other conditions, among them such economic aspects as the costs of studying related to, for example, the distance from one's hometown. This was confirmed by the study performed by the authors of this paper in 2014 based on surveys among the 2011/2012, 2012/2013 and 2013/2014 applicants for tertiary education at the West Pomeranian University of Technology in Szczecin (ZUT). The research revealed that in each year the main criterion when choosing the ZUT was the University's location (over $20 \%$ of the respondents), with the wide selection of courses and specializations (approx. 17\% of the respondents) and the quality of education (approx. 12\% of the respondents) only coming second and third, respectively ${ }^{1}$.

The article begins by profiling the applicants that chose to study at the Faculty of Economics of the West Pomeranian University of Technology in Szczecin in the academic year 2015/2016. In the study, the profiling phase was designed to help define both the dependent variable and the independent variables, which were subsequently used to verify the degree to which the applicants' entry skills measured by their matriculation examination results (for applicants to a full-time 1st cycle program) or the average grade awarded in the 1st cycle program (for applicants to a full-time 2nd cycle program) affect their achievement of learning outcomes.

The main objective of the study was to identify regularities with regard to the correlations between the applicants' skills and their learning outcomes. The purpose, in turn, was to use such data to adapt the teaching to the freshmen's level of knowledge and skills.

The study made use of the database of candidates applying for enrollment with the Faculty of Economics of the West Pomeranian University of Technology in Szczecin, Poland, registered in the Online Recruitment System for the academic year 2015/2016 (Data released by the ZUT IT Center - online registration was open from 25 May to 19 July 2015 (subsequently extended to 20 September 2015).

\section{PROFILE OF THE APPLICANTS TO FULL-TIME 1ST AND 2ND CYCLE PROGRAMS}

In the academic year 2015/2016, the applicants to the full-time 1st cycle (S1) program at the Faculty of Economics of the West Pomeranian University of Technology in Szczecin could apply for enrolment with three courses of study: Economics, Management, and Tourism and Recreation (TiR). As for the 2nd cycle program (S2), recruitment was only open for the course of study in Economics. Figure 1 presents a structure of the applicants registered in the Online Recruitment System, according to the cycle of studies and the course of study.

192 persons were admitted to the 1st cycle program, while the admission limit was exceeded (by 4 persons) only for the course of study in Management. Those admitted to this sort of study could be described as follows:

- sex: women (68.8\%), men (31.2\%);

- domicile: Szczecin (33.3\%), Zachodniopomorskie Voivodeship except for Szczecin $(52.6 \%)$, other voivodeships $(14.1 \%)$;

\footnotetext{
${ }^{1}$ Complete results of the study are provided in the paper by Bąk and Wawrzyniak (2015).
} 
- sort of senior secondary school completed: high school (76.6\%), technical secondary school (23.4\%);

- score awarded for the standard-level Mathematics matriculation exam: from 30 to 55 pts. (51.3\%), from 56 to 80 pts. (32.3\%), from 81 to 100 pts. (16.4\%);

- those who took the extended-level Mathematics exam (21.2\%).

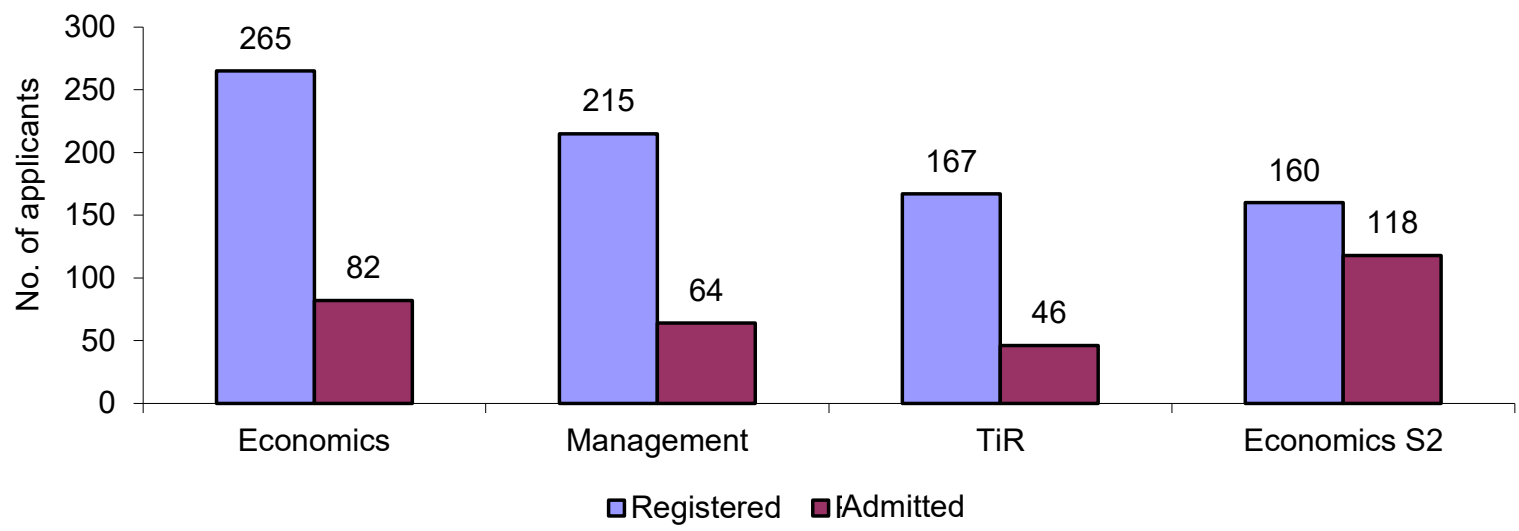

Fig. 1. Structure of applicants registered in the online system and admitted to the Faculty, according to the cycle of studies and the course of study

Source: developed by the authors.

Among freshmen admitted to the full-time 1st cycle program, the highest score was achieved by those applying to join the course of study in Economics, with most scoring between 60 and 90 pts. Most of those applying for enrollment with the other courses of study scored between 30 and 60 pts (Table 1). The number of points the given applicant scored was calculated using the University's algorithm that accounted for the so-called "new" matriculation exam results (Uchwała $\mathrm{nr} 40$ Senatu Zachodniopomorskiego Uniwersytetu Technologicznego w Szczecinie $z$ dnia 26 maja 2014 r.:

$$
L P=0.35 \cdot A \cdot W+0.2 \cdot B \cdot W+0.2 \cdot C \cdot W+0.25 \cdot D \cdot X
$$
where:

$A$ - points [\%] scored by the applicant for their matriculation exam in Mathematics (for applicants choosing the course of study in Economics and Management) or in the elective subject (Geography, Biology, Mathematics) (for applicants choosing the course of study in Tourism and Recreation);

$B$ - points [\%] scored by the applicant for their matriculation exam in the additional subject;

C - points [\%] scored by the applicant for their matriculation exam in Polish;

$D$ - points [\%] scored by the applicant for their matriculation exam in a (modern) foreign language;

$W$-coefficient that assumes the value of 1 for a standard-level exam in the given subject or 1.5 for an extended-level of exam;

$X$ - coefficient that assumes the value of 1 for a standard-level exam in a foreign language, 1.5 for an extended-level exam or 1.7 for applicants from high school bilingual programs. 
Table 1. Structure of applicants admitted to the first year according to their score divided into particular courses of study in the 1st cycle program [\%]

\begin{tabular}{|l|c|c|c|}
\hline \multicolumn{1}{|c|}{ Score } & Economics & Management & TiR \\
\hline $30-60$ & 35.4 & 64.1 & 56.6 \\
\hline $60-90$ & 54.8 & 29.6 & 39.1 \\
\hline $90-120$ & 9.8 & 6.3 & 4.3 \\
\hline Total & 100.0 & 100.0 & 100.0 \\
\hline
\end{tabular}

Source: developed by authors.

The 2nd cycle program admitted 118 people (with the admission limit set at 120 ), who could be characterized as follows:

- sex: women (74.6\%), men (25.4\%);

- domicile: Szczecin (35.6\%), Zachodniopomorskie Voivodeship except for Szczecin (50.0\%), other voivodeships (14.4\%);

- sort of higher education institution completed: the ZUT in Szczecin (72.9\%), the University of Szczecin $(18.6 \%)$, other $(8.5 \%)$;

- course of study completed: Economics (53.4\%), Management (15.3\%), TiR (10.2\%), other (21.1\%).

The applicants were admitted to the 2nd cycle program based on the average grade awarded in their 1st cycle studies. As Figure 2 indicates, the highest number of the admitted applicants had a grade between 3.50 and 3.99 , with only $8.5 \%$ of them scoring higher than 4.5 .

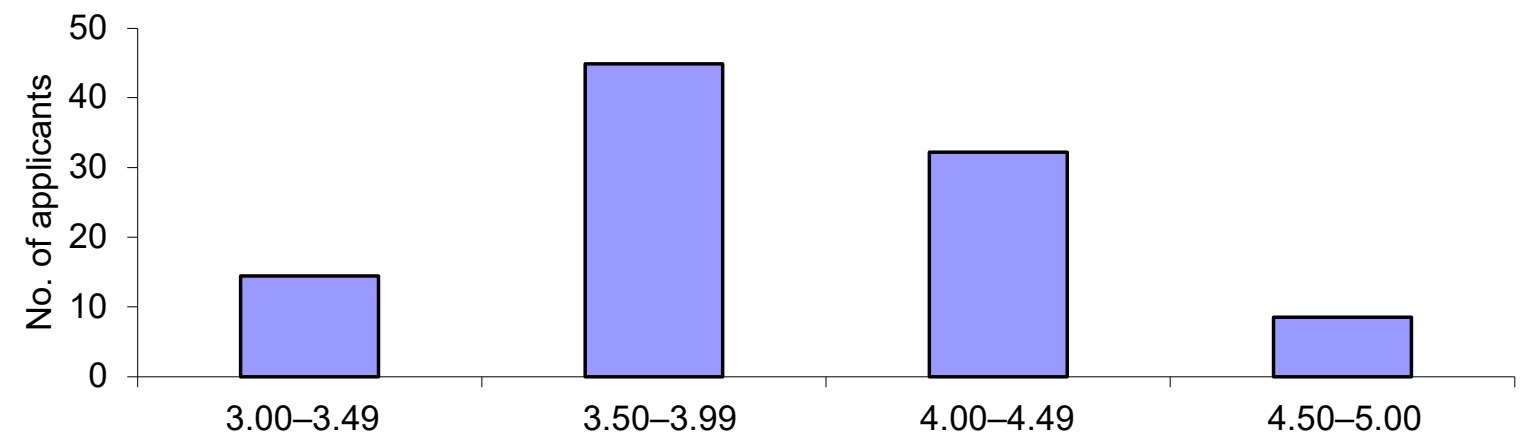

Fig. 2. Structure of applicants admitted to S2 according to their average grades for 1 st cycle studies [\%] Source: developed by the authors.

\section{ANALYSIS OF THE CORRELATIONS BETWEEN LEARNING OUTCOMES AND SELECTED VARIABLES CHARACTERIZING THE STUDENTS, USING MEASURES OF STRENGTH AND DIRECTION OF THE RELATIONSHIP}

The entry skills demonstrated by students admitted to the full-time 1st cycle program were defined through the numbers of points they achieved in the recruitment process (formula no. 1). This value was deemed to be the independent variable that could have an effect on the learning outcomes of the first years of study. Due to the availability of individual data, for these students the dependent variable was defined as the grade awarded during the passing procedure for first-semester Mathematics practical classes ${ }^{2}$. In the case of the full-time 2 nd cycle program,

${ }^{2}$ According to formula no. 1, in the courses of Economics and Management the highest weights were attributed to the score achieved for the matriculation exam in Mathematics. 
the independent variable was assumed to be the average grade awarded for the full-time 1st cycle program, and the dependent variable was deemed to be the exam grade for statistical inference. The values of the linear correlation coefficients between the aforementioned variables are shown in Table 2. It turned out that there was a low positive dependence between their skills and learning outcomes for the 1st cycle students, and a moderate positive dependence for the 2 nd cycle students.

Table 2. Pearson correlation coefficients between the final grades for selected subject and the recruitments scores

\begin{tabular}{|l|c|l|}
\hline \multicolumn{1}{|c|}{ Source/ sort of study } & \multicolumn{1}{|c|}{$\begin{array}{c}\text { Pearson correlation } \\
\text { coefficient }\end{array}$} & \multicolumn{1}{|c|}{ Dependent/ independent variable } \\
\hline Economics/ S1 & 0.296 & Mathematics grade/ Recruitment score \\
\hline Management/ S1 & 0.267 & $\begin{array}{l}\text { Statistical inference grade/ Average grade for the } \\
\text { studies }\end{array}$ \\
\hline Economics/ S2 & 0.492 & \\
\hline
\end{tabular}

Source: developed by the authors.

The next step entailed studying the dependence between the learning outcomes (with the student either passing or failing in their Mathematics or Statistical inference course passing procedure) and the selected qualitative variables characterizing the students. The statistical material was grouped in fourfold tables, which served as a basis for calculating Pearson's coefficient of contingency (C) according to the formula (Domański 1990; Steczkowski and Zeliaś 1997; Stanisz 2006; Bąk et al. 2017):

$$
\begin{aligned}
& C=\sqrt{\frac{\chi^{2}}{\left(n+\chi^{2}\right)}} \\
& \chi^{2}=\sum_{i=1}^{r} \sum_{j=1}^{s} \frac{\left(n_{i j}-\hat{n}_{i j}\right)^{2}}{\hat{n}_{i j}}
\end{aligned}
$$

where:

$n_{i j}$ - empirical frequencies, which denote the number of units in the population belonging to the $i$ group according to the variable $X(i=1,2, \ldots, r)$ and the $j$-th group according to the variable $Y(j=1,2, \ldots, s)$;

$\hat{n}_{i j}$ - theoretical frequencies, which are determined for particular combinations of variants of both the studied variables with the assumption of their independence according to the formula:

$$
\hat{n}_{i j}=\frac{n_{i .} \cdot n_{. j}}{n}
$$

where:

$n_{i .}$ - boundary frequencies, which denote the number of units of population belonging to the $i$-th group according to the variable $X(i=1,2, \ldots, r)$;

$n_{. j}$ - boundary frequencies, which denote the number of units of population belonging to the $j$-th group according to the variable $Y(j=1,2, \ldots, s)$;

$n-$ population frequency. 
Table 3 presents the values of Pearson's coefficients of contingency $(\mathrm{C})$ between the fact of passing or failing in the Mathematics practical class passing procedure and the variables characterizing the student. On their basis, it could be concluded that none of the selected variables affected the learning outcomes.

Table 3. Pearson's coefficients of contingency (C) between learning outcomes and selected variables of the 1st cycle program students

\begin{tabular}{|l|c|}
\hline \multicolumn{1}{|c|}{ Selected variable } & Pearson's coefficient of contingency (C) \\
\hline Sex (woman/man) & 0.085 \\
\hline Extended-level matriculation exam in Mathematics (Y/ N) & 0.065 \\
\hline $\begin{array}{l}\text { Type of completed secondary school (high school/ tech- } \\
\text { nical secondary) }\end{array}$ & 0.029 \\
\hline Course of study (Economics/ Management) & 0.059 \\
\hline
\end{tabular}

Source: developed by the authors.

In the same way it was verified whether or not there was a dependence between the passing rate for the statistical inference exam and the selected variables characterizing the 2 nd cycle program students (Table 4). The results show a moderate dependence between the learning outcomes and the completed course of study / higher education institution.

Table 4. Pearson's coefficients of contingency (C) between learning outcomes and selected variables of the 2nd cycle program students.

\begin{tabular}{|l|c|}
\hline \multicolumn{1}{|c|}{ Selected variable } & Person's coefficient of contingency (C) \\
\hline Sex (woman/man) & 0.216 \\
\hline Completed course of study (Economics, other) & 0.339 \\
\hline Completed higher education institution (the ZUT, other) & 0.336 \\
\hline $\begin{array}{l}\text { Sort of completed secondary school (high school/ tech- } \\
\text { nical secondary) }\end{array}$ & 0.154 \\
\hline
\end{tabular}

Source: developed by the authors.

\section{ANALYSIS OF THE CORRELATIONS BETWEEN LEARNING OUTCOMES AND SELECTED VARIABLES CHARACTERIZING THE 2ND CYCLE PROGRAM STUDENTS, USING LOGISTIC REGRESSION}

On the basis of an analysis of the above-described correlation, it was observed that for the 2nd cycle program (S2) students there was a moderate dependence between their learning outcomes and the completed higher education institution ( $\mathrm{HEI})$, as well as the completed course of study (Table 4). For these variables, a binomial logit model of the following form was estimated ${ }^{3}$ :

$$
p_{i}=\frac{1}{1+\exp \left(-x_{i}^{T} \beta\right)}
$$

where:

$p_{i}-$ probabilities defined as $P\left(Y_{i}=1\right)=p_{i}$ and $P\left(Y_{i}=0\right)=1-p_{i}$,

$Y_{i}$ - a dummy variable assuming the value of 1 if the student passed the Statistical Inference exam, and the value of 0 if they failed,

$x_{i}-$ values of independent variables for particular cases,

$\beta$-structural parameters.

\footnotetext{
${ }^{3}$ Descriptions of logit models can be found in the papers of, for example: Wiśniewski (1986); Statystyczne metody... (1998); Zeliaś et al. (2003); Maddala (2006, 2008); Gruszczyński (2001); Mikroekonometria... (2010).
} 
The set of independent variables contained two dummy variables $X_{1}$ and $X_{2}$, the variants of which were defined as follows:

$X_{1}: 1$ - graduation from the 1 st cycle program at the ZUT in Szczecin, 0 - graduation from another $\mathrm{HEl}$;

$X_{2}: 1$ - completion of a course of study in Economics ${ }^{4}, 0$ - completion of a different one.

The accuracy of the estimated model was verified with the likelihood-ratio test, which is designed to verify the null hypothesis claiming that all the model parameters - except the constant term - equal zero. The statistic of the test is expressed in the formula (Mikroekonometria... 2010):

$$
x^{2}=2\left(\ln L_{U R}-\ln L_{R}\right)
$$

where:

$L_{U R}$ - value of the likelihood function for a complete model,

$L_{R}-$ value of the likelihood function reduced to the constant term.

Prediction efficiency can be measured using the measures determined on the basis of the classification accuracy table (Table 5).

Table 5. Accuracy table

\begin{tabular}{|l|c|c|c|}
\hline \multirow{2}{*}{ Actual } & \multicolumn{2}{|c|}{ Predicted } & \multirow{2}{*}{ Total } \\
\cline { 2 - 3 } & $\hat{y}_{i}=1$ & $\hat{y}_{i}=0$ & $n_{1}$. \\
\hline$y_{i}=1$ & $n_{11}$ & $n_{10}$ & $n_{0}$ \\
\hline$y_{i}=0$ & $n_{01}$ & $n_{00}$ & $n$ \\
\hline Total & $n_{.1}$ & $n_{.0}$ & \\
\hline
\end{tabular}

Source: Mikroekonometria... (2010).

The theoretical values of the dependent variable $\left(\hat{y}_{i}\right)$ can be determined according to the standard prediction rule (Mikroekonometria... 2010):

$$
\hat{y}_{i}=\left\{\begin{array}{lll}
1 & \text { gdy } & 0,5<\hat{p}_{i} \leq 1 \\
0 & \text { gdy } & 0 \leq \hat{p}_{i} \leq 0,5
\end{array}\right.
$$

where:

$\hat{p}_{i}$ - theoretical probabilities derived from the logistic regression model estimated on the basis of a random trial.

In situations where the sample is disproportionate, i.e. one where the percentage of observations for which $y_{i}=1$ is much higher or lower than $50 \%$, the theoretical values can be predicted using a modification of the standard rule and the predictions can be calculated according to the optimal boundary value a rule (Gruszczyński 2001):

$$
\hat{y}_{i}=\left\{\begin{array}{lll}
1 & \text { gdy } & \alpha<\hat{p}_{i} \leq 1 \\
0 & \text { gdy } & 0<\hat{p}_{i} \leq \alpha
\end{array}\right.
$$

The boundary value $\alpha$ is established at the level of the actual percentage of observations in the sample for which $y_{i}=1$ (Mikroekonometria... 2010) ${ }^{5}$.

\footnotetext{
${ }^{4}$ If the applicant had completed a course of study in Economics they were not required to take the entrance interview as per the recruitment rules.

${ }^{5}$ Other methods for determining the level of $\alpha$ with a disproportionate sample are provided in the paper Mikroekonometria... (2010).
} 
Using the accuracy tables (Table 5) two measures were determined:

1) count $R^{2}$ (overall classification accuracy)

$$
R^{2}=\frac{n_{00}+n_{11}}{n} \cdot 100 \%
$$

2) odds ratio (IS)

$$
\text { IS }=\frac{n_{11} \cdot n_{00}}{n_{01} \cdot n_{10}}
$$

The value of count $R^{2}$ denotes the percentage of accurately classified cases (Maddala 2006, 2008). The closer the measure is to zero the more the model fits the empirical data characterizing the phenomenon being studied ${ }^{6}$. As for the odds ratio, the higher the measure is than 1 the better the classification obtained on the basis of the model.

The logit model parameters were estimated using the statistical package Statistica 10.0. To ensure that conclusions drawn from the model estimated for the whole population would allow reliable interpretation, logit model parameters using the bootstrapping method were determined additionally ${ }^{7}$. The calculations were performed using the software named $R$, which rendered a special code accounting for the procedures and instructions required in the computational process. Bootstrapping regression consists in $B$-fold random sampling with replacement $(B>1000)$ of the rows originating from the observation matrix $[y, X]$, where $y$ denotes the observation vector for the dependent variable, and $X$ denotes the observation matrix for the independent variables. Let us use $w_{i}(i=1,2, \ldots, n)$ to denote the $i$-th row of the vector $y$ and the matrix $X: w_{i}=\left(y_{i}, x_{i}\right)$. The analyzed set can be considered as a set of vectors:

$$
W=\left|\begin{array}{c}
w_{1} \\
w_{2} \\
\cdots \\
w_{n}
\end{array}\right|
$$

The process of resampling and estimating the model parameters was performed 10,000 times, whereas bootstrap regression in the logit model was carried out in the following stages (Domański et al. 1998):

1. The $b$-th bootstrap sample was built $(b=1,2, \ldots, B)$ :

$$
W^{b}=\left|\begin{array}{c}
\mathbf{w}_{1}^{b} \\
\mathbf{w}_{2}^{b} \\
\ldots \\
\mathbf{w}_{n}^{b}
\end{array}\right|
$$

random sampling with replacement the number $n$ of vectors $w_{i}$ from the set $W$.

2. Based on the bootstrap sample, the logit model parameters were estimated as follows:

$$
p_{i}^{b}=\frac{1}{1+\exp \left(-\boldsymbol{x}_{i}^{(b) T} \boldsymbol{\beta}^{b}\right)}
$$

\footnotetext{
${ }^{6}$ The most popular measures of goodness of fir of the binomial model to the empirical data can be found, for example, in the paper edited by Mikroekonometria... (2010).

${ }^{7}$ Bootstrap methods consist in inference based on multiple random sampling with replacement. They are therefore based on actual data. Their aim is to establish an approximation of the unknown distribution of a random variable of interest in the given study, or rather a statistic being the function of the estimator of an unknown parameter of the unknown distribution of the i-th parameter (Suchecka, Nieszporska 2000).
} 
where:

$\boldsymbol{x}_{i}^{(b)}-$ vector of the values of the independent variables for the given bootstrap sample,

$\boldsymbol{\beta}^{b}$ - vector of the structural parameters of the logit model built on the basis of the given bootstrap sample.

3. Steps 1 and 2 were repeated $r$ times ( $r=1,2, \ldots, B$, where $B$ was the number of replications).

4. The resultant distributions $F\left(\hat{\beta}^{b}\right)$ of the parameters calculated on the basis of subsequent bootstrap samples $\hat{\beta}^{(1)}, \hat{\beta}^{(2)}, \ldots, \hat{\beta}^{(B)}$ were used to determine the unbiased estimators of the parameter vector $\boldsymbol{\beta}$ of the logit function:

$\hat{\beta}_{(b)}=\frac{1}{B} \sum_{b=1}^{B} \hat{\beta}^{b}$

5. The logit model of the variable $Y$ estimated using the bootstrap method was as follows:

$$
p_{i}=\frac{1}{1+\exp \left(-x_{i}^{T} \hat{\beta}_{(b)}\right)}
$$

where:

$\hat{\beta}_{(b)}$ were unbiased estimators of the parameters $\beta$ obtained using the formula no. 14.

Table 6 presents the estimation results obtained on the basis of the population studied and those obtained using the bootstrap method. The values of the estimated parameters using both the methods were similar, while the only difference being related to the measures connected with model verification - for the bootstrap model the odds ratio and the overall classification accuracy improved. As the population was disproportionate, the theoretical values of the dependent variable were determined using the formula no. 8, assuming an $\alpha$ of 0.763 . On the basis of the estimated model it could be concluded that the probability of passing the exam in Statistical Inference was significantly affected by graduation from the ZUT in Szczecin or from courses of study in Economics. The values of the unit odds ratios calculated for individual independent variables suggested that the probability of passing the exam was almost five times as high for those students who had graduated from the 1st cycle program at the ZUT in Szczecin, and over three times as high for those who had completed courses of study in Economics.

Table. 6. Results of logit model estimations for the variable $y$ on the basis of the population and using the bootstrap method

\begin{tabular}{|l|c|c|c|c|c|c|c|c|}
\hline \multirow{2}{*}{ Variable } & \multicolumn{4}{|c|}{ Logit model } & \multicolumn{4}{c|}{ Logistic (bootstrap) model } \\
\cline { 2 - 9 } & $\begin{array}{c}\text { parameter } \\
\text { assess- } \\
\text { ment }\end{array}$ & $\begin{array}{c}\text { average } \\
\text { error of } \\
\text { estimate }\end{array}$ & $\begin{array}{c}\text { student's t } \\
\text { statistics }\end{array}$ & odds ratio & $\begin{array}{c}\text { parameter } \\
\text { assess- } \\
\text { ment }\end{array}$ & $\begin{array}{c}\text { average } \\
\text { error of } \\
\text { estimate }\end{array}$ & $\begin{array}{c}\text { student's t } \\
\text { statistics }\end{array}$ & odds ratio \\
\hline $\begin{array}{l}\text { Constant } \\
\text { term }\end{array}$ & -0.749 & 0.528 & -1.418 & - & -0.780 & 0.558 & -1.355 & - \\
\hline$X_{1}$ & 1.570 & 0.480 & 3.271 & 4.807 & 1.645 & 0.505 & 3.241 & 5.181 \\
\hline$X_{2}$ & 1.211 & 0.517 & 2.345 & 3.358 & 1.241 & 0.546 & 2.286 & 3.459 \\
\hline $\begin{array}{l}\chi^{2}=17.424 d f=2 p=0.000^{8} \\
\text { IS }=7.000 \\
\text { Overall classification accuracy: } 71.19 \%\end{array}$ & & $\begin{array}{l}\chi^{2}=19.774 \\
\text { IS }=8.830 \\
\text { Overall classification accuracy: } 73.0 \%\end{array}$ \\
\hline
\end{tabular}

Source: the authors' own calculations.

${ }^{8} d f$ - number of degrees of freedom, $p$ - p-value, IS - odds ratio (formula no. 10), overall classification accuracy (formula no. 9). 


\section{CONCLUSION}

On the basis of studies carried out the following conclusions could be drawn as regards the profile of applicants to the Faculty of Economics of the ZUT in Szczecin in the academic year 2015/2016 and the correlations between the applicants' entry skills and their learning outcomes at the University:

1) the number of applicants admitted in the academic year 2015/2016 was lower than in the previous years, with the recruitment limits only exceeded in the 1st cycle courses of study in Economics - which was in line with the overall trend in Poland;

2) approx. $90 \%$ of the applicants admitted to both the 1st and 2nd cycles (S1 and S2) programs were inhabitants of Zachodniopomorskie Voivodeship, with a third of them living in Szczecin - which confirmed the result of the authors' earlier research into the significance of location when choosing the HEl to study at;

3) $73 \%$ of the students admitted to the 2 nd cycle program had graduated from the 1 st cycle program at the ZUT in Szczecin - which also confirmed the finding that the University's location had a considerable impact on its choice as the venue for a graduate course;

4) most of those admitted to the 1st cycle program were applicants who received a score from 30 to 60 points, and the prevailing number of those admitted to the 2 nd cycle program had an overall average grade awarded in their 1st cycle subjects ranging between 3.5 and 3.99 - their entry skills were average, which meant that better-skilled students were unfortunately choosing to apply for enrolment with another Faculty, or another higher education institution;

5 ) in the case of the 1st cycle program, there was a low positive correlation between the recruitment score (the number of points awarded) and the passing grade for practical classes in Mathematics, which meant that in the first year of the 1st cycle program the entry skills did not have a significant impact on achieving higher learning outcomes in Mathematics the cause of this relationship might have been the fact that the teaching and learning methods at universities were different to those at secondary schools, and thus even those persons who had very good grades in their secondary schools encountered difficulties during their 1st year at universities; this explanation was confirmed for 1st cycle students by the identified lack of dependence between learning outcomes and selected qualitative values: sex, sort of completed high school and the chosen course of study;

6 ) in the case of the 2 nd cycle program, the correlation between the learning outcomes measured using the Statistical Inference examination scores and the recruitment scores was moderately positive, which meant that in the 1 st year of the 2 nd cycle program those students who had better grades at the end of their 1st cycle program scored better at the Statistical Inference examination - the cause of this relationship might have been the fact that they had acquired learning skills during their 1st cycle studies, as well as the fact that they were continuing their studies at the same University and within the same course of study, which meant they already knew what was expected of them by - very often the same teachers that they had had in their undergraduate studies.

7) the causes stated in point 6 above were confirmed in the study of the dependence between the Statistical Inference examination score and the type of higher education institution and the course of study - on the basis of the value of Pearson's coefficient of contingency (C) 
a moderate dependence was identified between these values, whereas the estimated binomial logit model showed that the 2nd full-time program students who had completed their 1st cycle program at the ZUT in Szczecin were five times as likely to pass their Statistical Inference examination, with those who had graduated from courses of study in Economics being three times as likely;

8) although the results of this study were specifically related to the applicants to and students of the Faculty of Economics at the ZUT in Szczecin in the specific academic year, they can serve as a suggestion for teachers and lecturers from other Faculties and HEls that it is necessary to adapt the teaching process to the knowledge and skills possessed by the freshmen.

\section{REFERENCES}

Bąk I., Wawrzyniak K. 2015. Ocena oczekiwań studentów względem procesu nauczania jako źródła wiedzy i umiejętności niezbędnych do podjęcia pracy zawodowej - wyniki badań ankietowych, w: Nauczyciel akademicki wobec nowych wyzwań edukacyjnych. Red. P. Wdowiński. Łódź, Wydaw. UŁódz, 57-71. [in Polish]

Bąk I., Markowicz I., Mojsiewicz M., Wawrzyniak K. 2017. Statystyka opisowa. Przykłady i zadania. Warszawa, CeDeWu Sp. z o.o., 101. [in Polish]

Domański C. 1990. Testy statystyczne. Warszawa, PWE, 166-168. [in Polish]

Domański C., Pruska, K., Wagner W. 1998. Wnioskowanie statystyczne przy nieklasycznych założeniach. Łódź, Wydaw. UŁódz., 124-126. [in Polish]

Gruszczyński M. 2001. Modele i prognozy zmiennych jakościowych w finansach i bankowości. Warszawa, Oficyna Wydaw. SGH. [in Polish]

Mikroekonometria. Modele i metody analizy danych indywidualnych. 2010. Red. M. Gruszczyński Warszawa, Wolters Kliwer Polska, 65, 73, 71-79. [in Polish]

Maddala GS. 2006, 2008. Ekonometria. Warszawa, PWN, 379. [in Polish]

Mikuła-Bączek E. 2016. Przeobrażenia instytucjonalne a jakość edukacji szczebla wyższego w Polsce w latach 1990-2006, http://www.ur.edu.pl/pliki/Zeszyt14/37.pdf, access: 28.10.2019. [in Polish]

Statystyczne metody analizy danych. 1998. Red. W. Ostasiewicz. Wrocław, AE. [in Polish]

Rocznik Statystyczny Rzeczypospolitej Polskiej. 2004. Warszawa, GUS. [in Polish]

Rocznik Statystyczny Rzeczypospolitej Polskiej. 2013. Warszawa, GUS. [in Polish]

Rocznik Statystyczny Rzeczypospolitej Polskiej. 2015. Warszawa, GUS. [in Polish]

Rocznik Statystyczny Rzeczypospolitej Polskiej. 2018. Warszawa, GUS. [in Polish]

Steczkowski J., Zeliaś A. 1997. Metody statystyczne w badaniu zjawisk jakościowych. Kraków, AE. [in Polish]

Stanisz A. 2006. Przystępny kurs statystyki z zastosowaniem STATISTICA PL na przykładach medycyny. T. 1. Statystyki podstawowe. Kraków, StatSoft Polska, 326. [in Polish]

Suchocka J., Nieszporska S. 2000. Metoda bootstrapowa w estymacji wskaźników koszt-efektywność [Bootstrap procedure in estimating cost-effectiveness ratio]. Taksonomia 7, 36-37. [in Polish]

Uchwała nr 40 Senatu Zachodniopomorskiego Uniwersytetu Technologicznego w Szczecinie z dnia 26 maja 2014 r., http://zut.edu.pl/apzut/, access: 26.10.2019.

Wiśniewski J.W. 1986. Ekonometryczne badanie zjawisk jakościowych. Toruń, Wydaw. UMK. [in Polish]

Zeliaś A., Pawełek B., Wanat S. 2003. Prognozowanie ekonomiczne. Teoria, przykłady, zadania. Warszawa, PWN, 175. [in Polish] 


\section{CHARAKTERYSTYKA KANDYDATÓW NA STUDIA A EFEKTY KSZTAŁCENIA}

Streszczenie. Celem badań przedstawionych w artykule było uzyskanie odpowiedzi na pytanie, na ile umiejętności kandydata, mierzone wynikami otrzymanymi na egzaminie maturalnym (na studiach stacjonarnych pierwszego stopnia) lub średnią oceną ze studiów pierwszego stopnia (na studiach stacjonarnych drugiego stopnia), wpływają na realizację efektów kształcenia. Aby odpowiedzieć na powyższe pytanie, przeprowadzono analizę zależności pomiędzy umiejętnościami studenta a efektami kształcenia, z wykorzystaniem miar siły i kierunku związku oraz regresji logitowej. Podstawę informacyjną badań stanowiła baza danych o kandydatach na Wydział Ekonomiczny Zachodniopomorskiego Uniwersytetu Technologicznego w Szczecinie, którzy zarejestrowali się w internetowym systemie rekrutacji w roku akademickim 2015/2016.

Słowa kluczowe: kandydaci na studia, efekty kształcenia, miary siły i kierunku związku, regresja logitowa, metoda bootstrapowa. 